\title{
Micronutrient Availability from Steel Slag Amendment in Peatmoss Substrates
}

\author{
James E. Altland ${ }^{\mathbf{1}}$ and Charles Krause \\ USDA-ARS, Application Technology Research Unit, 27 Horticultural Insects \\ Research Laboratory, 1680 Madison Avenue, Wooster, OH 44691
}

James C. Locke and Wendy L. Zellner

USDA-ARS, Application Technology Research Unit, Greenhouse Production

Research Group, 2801 W. Bancroft Street, Mail Stop 604, Toledo, OH 43606

Additional index words. substrates, plant nutrition, container crops, $\mathrm{pH}$, fertilizer

\begin{abstract}
The objective of this research was to determine the suitability of a steel slag product for supplying micronutrients to container-grown floriculture crops. Geranium (Pelargonium $\times$ hortorum L.H. Bailey 'Maverick Red') and tomato (Solanum lycopersicon L. 'Megabite') were grown in 11.4-cm containers with a substrate composed of 85 peatmoss : 15 perlite (v/v). A group of containers referred to as the commercial control (C-control) were amended with $4.8 \mathrm{~kg} \cdot \mathrm{m}^{-3}$ dolomitic lime and fertilized with a commercial complete fertilizer providing macro and micronutrients (Jack's $20 \mathrm{~N}-4.4 \mathrm{P}-16.6 \mathrm{~K}-$ $0.15 \mathrm{Mg}-0.02 \mathrm{~B}-0.01 \mathrm{Cu}-0.1 \mathrm{Fe}-0.05 \mathrm{Mn}-0.01 \mathrm{Mo}-0.05 \mathrm{Zn}$ ) at a concentration of $100 \mathrm{mg} \cdot \mathrm{L}^{-1}$ nitrogen (N). Another group of containers, referred to as the micronutrient control (M-control), were amended with a commercial granular micronutrient package at $0.9 \mathrm{~kg} \cdot \mathrm{m}^{-3}$ and dolomitic lime at $4.8 \mathrm{~kg} \cdot \mathrm{m}^{-3}$. The M-controls were fertilized with $7.1 \mathrm{~mm} N\left(100 \mathrm{mg} \cdot \mathrm{L}^{-1} \mathrm{~N}\right)$ with ammonium nitrate and $2 \mathrm{~mm}$ potassium phosphate. A final group of containers were amended with $1.2,2.4$, or $4.8 \mathrm{~kg} \cdot \mathrm{m}^{-3}$ of steel slag and fertilized with 3.6 mM ammonium nitrate and $2 \mathrm{~mm}$ potassium phosphate. Both control groups resulted in vigorous and saleable plants by the conclusion of the experiment. In both crops, chlorophyll levels, root ratings, and shoot dry mass were lower in all steel slag-amended plants compared with either control groups. In geranium, foliar nutrient concentrations suggest $\mathrm{Cu}$ and $\mathrm{Zn}$ were limiting whereas $\mathrm{B}$ and $\mathrm{Zn}$ were limiting in tomato. Based on the results of this research, steel slag does not provide sufficient micronutrients, most notably $B$, $\mathrm{Cu}$, and $\mathrm{Zn}$, to be the sole source of micronutrient fertilization in container-grown crops.
\end{abstract}

Soilless substrates used in U.S. floriculture are comprised primarily of sphagnum peatmoss amended with perlite, vermiculite, pumice, and to a lesser extent sand, compost, and other components. Sphagnum peatmoss does not contain sufficient micronutrients (B, Fe, Mn, Cu, Mo, $\mathrm{Zn}$ ) to support vigorous crop growth. Plants grown in peatmoss without added micronutrients have been shown to be deficient in $\mathrm{Cu}$ (Adams et al., 1986), B and Fe (Smilde, 1975), Zn (Penningsfeld, 1972), and Mo (Cox, 1988). These and other papers have shown that micronutrient deficiencies are often an interacting function of micronutrient application, lime application, and substrate pH (Smith et al., 2004).

Micronutrients are primarily supplied to containerized floriculture crops by one of two methods. Many producers use a water-soluble fertilizer that provides macronutrients $(\mathrm{N}, \mathrm{P}$, and $\mathrm{K})$ as well as all secondary nutrients ( $\mathrm{Ca}$, $\mathrm{Mg}$, and S) and micronutrients. This fertilization method provides low concentrations of water-soluble micronutrient salts or chelates

Received for publication 18 Aug. 2015. Accepted for publication 30 Sept. 2015.

${ }^{1}$ Corresponding author. E-mail: james.altland@ ars.usda.gov. with each irrigation event. Depending on the irrigation system, micronutrients in these water-soluble fertilizers could be applied to the substrate (via drip irrigation) or to the foliage and substrate (via overhead irrigation booms). Micronutrients can also be incorporated into the substrate using a granular formulation. These products include varying concentrations of each micronutrient, usually in a water-soluble salt or chelate, but sometimes as finely ground minerals with limited solubility that presumably render the micronutrients available slowly over time. Frost et al. (2003) showed that either water-soluble or granular incorporated fertilizers are effective in providing micronutrients; however, geranium (Pelargonium $\times$ hortorum 'Orbit Red') relative growth rate was higher with water-soluble micronutrients in the irrigation stream.

Steel slag is a by-product of the steel industry with high mineral nutrient content. As steel scraps and iron ore are melted in a basic oxygen furnace, calcium oxide $(\mathrm{CaO})$ and dolomitic lime are introduced as fluxing agents to remove impurities from the molten steel. Mineral impurities removed by the fluxing agents, along with the $\mathrm{CaO}$ and dolomitic lime, form a molten slag. The slag is poured off from the steel, cooled, and processed into particle size fractions ranging from dust to gravel. Steel slag has been shown to be an effective liming agent for soilless substrates in container culture (Altland et al., 2015) as well as field soils (Ali and Shahram, 2007; Rodriguez et al., 1994).

The impurities removed from the molten steel by the fluxing agent include varying concentrations of elements considered to be plant micronutrients. Properties of steel slag and the elemental content of the impurities vary by the type of furnace in which steel is produced (Yildirim and Prezzi, 2011). Despite differences, most steel slags are similar in that they are composed primarily of $\mathrm{CaO}$, $\mathrm{SiO}_{2}$, and $\mathrm{FeO}$, with $\mathrm{CaO}$ making up more than $35 \%$ of steel slag mass (Yildirim and Prezzi, 2011). Although micronutrients are present in steel slag, the mineral form of the micronutrients may or may not render them available for plant uptake. Furthermore, the high $\mathrm{CaO}$ content of the steel slag causes a rapid increase in substrate $\mathrm{pH}$ (Altland et al., 2015), which could render many of the micronutrients less available for plant uptake (Peterson, 1980). Therefore, the objective of this research was to determine if steel slag could be used as the sole micronutrient source for container-grown floriculture crops in a peatmoss-based substrate.

\section{Materials and Methods}

Geranium (Pelargonium $\times$ hortorum 'Maverick Red') and tomato (Solanum lycopersicon 'Megabite') were sown in a 288-cell flat filled with Sunshine Mix no. 2 (Sun Gro Horticulture, Seba Beach, Ablerta, Canada) on 7 May 2014. Seedlings were transplanted, by treatment, on 4 June 2014. The base substrate used in the experiment was composed of 85 peatmoss : 15 perlite (v/v) blend using sphagnum peatmoss (Sun Gro Horticulture) and medium grade coarse perlite (Sun Gro Horticulture). The C-control containers were filled with the base substrate amended with $4.8 \mathrm{~kg} \cdot \mathrm{m}^{-3}$ dolomitic lime (ECOPHRST; National Lime and Stone Co., Findlay, $\mathrm{OH}$ ) and they were potted with a single geranium or tomato plant, and thereafter fertilized with a commercial complete fertilizer providing macro and micronutrients (Jack's $20 \mathrm{~N}-4.4 \mathrm{P}-16.6 \mathrm{~K}-0.15 \mathrm{Mg}-\quad 0.02 \mathrm{~B}-$ $0.01 \mathrm{Cu}-0.1 \mathrm{Fe}-0.05 \mathrm{Mn}-0.01 \mathrm{Mo}-0.05 \mathrm{Zn}, \quad \mathrm{JR}$ Peters, Inc., Allentown, PA) at a concentration of $100 \mathrm{mg} \cdot \mathrm{L}^{-1}$ nitrogen $(\mathrm{N})$. The M-control containers were filled with the base substrate amended with a commercial granular micronutrient package (Micromax, 6Ca-3Mg-12S$0.1 \mathrm{~B}-17 \mathrm{Fe}-2.5 \mathrm{Mn}-1 \mathrm{Cu}-0.05 \mathrm{Mo}-1 \mathrm{Zn}$, The Scotts Co., Marysville, $\mathrm{OH}$ ) at $0.9 \mathrm{~kg} \cdot \mathrm{m}^{-3}$ and dolomitic lime at $4.8 \mathrm{~kg} \cdot \mathrm{m}^{-3}$ and they were fertilized with $3.6 \mathrm{~mm}$ ammonium nitrate $\left(100 \mathrm{mg} \cdot \mathrm{L}^{-1} \mathrm{~N}\right)$ and $2 \mathrm{~mm}$ potassium phosphate. A final group of containers were filled with the base substrate amended with 1.2, 2.4, or $4.8 \mathrm{~kg} \cdot \mathrm{m}^{-3}$ of steel slag (Plant Tuff, 0.004B$20.3 \mathrm{Fe}-2.22 \mathrm{Mn}-0.004 \mathrm{Cu}-0.00017 \mathrm{Mo}-0.017 \mathrm{Zn}$, Plant Tuff Inc., Dearborn, MI) and fertilized with $3.6 \mathrm{~mm}$ ammonium nitrate and $2 \mathrm{~mm}$ potassium phosphate. Each amended substrate was filled into twelve, $11.4-\mathrm{cm}$-diameter 
containers $\left(\approx 600 \mathrm{~cm}^{3}\right.$ volume). A $15-\mathrm{cm}$ diameter clear vinyl saucer (Hummert Intl., Earth City, MO) was placed beneath each container to capture leachate and allow it to be reabsorbed by the substrate. Containers were fertigated as needed using the aforementioned treatment-specific nutrient solutions. Initially, containers were irrigated $\approx 100 \mathrm{~mL}$ every other day, and gradually up to $200 \mathrm{~mL}$ every 1 to $2 \mathrm{~d}$. Containers were irrigated individually with a beaker. Purified water $\left(18 \mathrm{M} \Omega \cdot \mathrm{cm}^{-1}\right)$ was used for making all fertilizer solutions in this experiment. Containers were arranged in a completely randomized design on a bench in a glass-covered greenhouse in Toledo, $\mathrm{OH}$. The glasshouse was maintained between 21 and $27{ }^{\circ} \mathrm{C}$ throughout the experiment. Natural light was supplemented with high-pressure sodium lamps if light levels fell below $200 \mathrm{~W} \cdot \mathrm{m}^{-2}$ between 6:00 AM and 7:00 PM.

Micronutrient concentrations, in percent dry mass of the fertilizers, are provided in Table 1 . The quantity applied per container $(\mathrm{mg})$ is also provided. For the water-soluble fertilizer in the C-controls, the quantity applied was estimated based on the concentration of each nutrient in the dry fertilizer, the fertilizer application rate, and the volume and frequency of irrigation. For the granular micronutrient fertilizer in the M-control and the slag material, the amount applied was calculated and based on the application rate and substrate volume.

After mixing the substrates, four samples of each substrate type were analyzed for diethylene triamine pentaacetic acid (DTPA) extractable micronutrients using a method described by Warncke (1990). Briefly, $\approx 400 \mathrm{~mL}$ of substrate was filled into a glass jar and saturated with $5 \mathrm{~mm}$ DTPA. The media remained saturated for $24 \mathrm{~h}$, after which it was filtered (Q5 filter paper; Fisherbrand, Waltham, MA) under vacuum. Filtrate concentration of micronutrients were determined by adding $1 \mathrm{~mL}$ of solution sample with $9 \mathrm{~mL}$ of $3.89 \% \mathrm{HNO}_{3}$ in $18 \mathrm{M} \Omega \cdot \mathrm{cm}^{-1}$ water, and then analyzing with optical emission spectroscopy (iCAP 6300 Duo; Thermo Scientific, Waltham, MA).

At 3 and 5 weeks after planting (WAP), six replicates from every treatment were randomly selected and destructively harvested for the following analyses. Relative chlorophyll content was determined weekly with a chlorophyll meter (Minolta-502 SPAD meter; Spectrum Technologies, Inc., Plainfield, IL) by taking a measurement on five leaves per container and recording the mean. Containers were subjected to the pourthrough technique (Yeager et al., 2007) to collect a $50-\mathrm{mL}$ sample of the substrate solution for measurement of $\mathrm{pH}$, electrical conductivity (EC), and nutrient analysis. Substrate solutions were immediately measured for $\mathrm{pH}$ and $\mathrm{EC}$ then frozen until a nutrient analysis was performed. At the time of nutrient analysis, samples were thawed, filtered through $\mathrm{GF} / \mathrm{F}$ binder-free borosilicate glass fiber filter paper (Whatman Ltd., Kent, UK) to remove particles greater than $0.7 \mu \mathrm{m}$. The filtrate was then analyzed for concentration of micronutrients by adding $1 \mathrm{~mL}$ of solution sample with $9 \mathrm{~mL}$ of $3.89 \% \mathrm{HNO}_{3}$ in $18 \mathrm{M} \Omega$ water. This solution was analyzed with optical emission spectroscopy. Recently matured foliage was harvested for foliar nutrient analysis (Mills and Jones, 1996), rinsed with deionized water, then oven-dried at $55{ }^{\circ} \mathrm{C}$ for $3 \mathrm{~d}$. Samples were ground in a mill (Tecator Cyclotec AB, Hogenas, Sweden) through a $0.5-\mathrm{mm}$ screen. Foliar $\mathrm{N}$ was determined measuring $\approx 2.5 \mathrm{mg}$ of dry tissue into tin capsules (Costech Analytical, Valencia, CA) and analyzed with a CHNS/O PerkinElmer 2400 Series II Analyzer (PerkinElmer, Waltham, MA). Other macronutrients and micronutrients were determined by measuring $\approx 0.15 \mathrm{~g}$ dried tissue into a $55-\mathrm{mL}$ Teflon vessel with $5.0 \mathrm{~mL}$ of nitric acid $(15.8 \mathrm{~N})$. Vessels were heated in a programmable microwave (MARS 6; CEM Corp., Matthews, NC) by ramping the temperature up to $200{ }^{\circ} \mathrm{C}$ for $15 \mathrm{~min}$, then maintaining that temperature for $20 \mathrm{~min}$. After digestion, vessels were cooled to room temperature, $1.5 \mathrm{~mL}$ of $\mathrm{H}_{2} \mathrm{O}_{2}$ was added, and samples were heated again by ramping the temperature back to $200{ }^{\circ} \mathrm{C}$ over $15 \mathrm{~min}$ and holding that temperature for an additional $20 \mathrm{~min}$. Vessels were cooled again and $12 \mathrm{~mL}$ of deionized water (18 M $\Omega$ ) was added to the vessels. The solution was then filtered (Whatman's no. 2) and from that, $1.3 \mathrm{~mL}$ of the filtrate was diluted with $8.7 \mathrm{~mL}$ deionized water and analyzed with optical emission spectroscopy. Immediately after leaf tissue harvests, shoot dry weight (SDW) was determined by removing the shoot portion of the plant, oven-drying at $55^{\circ} \mathrm{C}$ for $3 \mathrm{~d}$, and weighing. Roots visibly growing along the root ball-container interface were subjectively rated on a scale from 0 to 5 where $0=$ no roots visible and $5=100 \%$ of the interface covered by white, healthy roots.

Data were subjected to analysis of variance and the least significant difference (LSD) was determined with Fisher's protected LSD, where $\alpha=0.05$. Orthogonal contrast analysis was used to determine if there was a significant rate response from steel slag incorporation rate in each measured parameter.

\section{Results and Discussion}

Extractable B, Fe, and Mn were lowest in the C-control substrate (Table 2). This was expected, as the C-control substrate would not have yet received micronutrients via water-soluble fertilizer applications. With the exception of Fe, DTPA-extractable micronutrients were highest in M-control substrates. Despite application of very high Fe quantities from the steel slag amendment, only the low rate of steel slag $\left(1.2 \mathrm{~kg} \cdot \mathrm{m}^{-3}\right)$ resulted in greater DTPA-extractable $\mathrm{Fe}$ compared with the C-control substrate. As the steel slag rate increased, DTPAextractable Fe decreased. Steel slag provided no additional DTPA-extractable $\mathrm{Cu}$ or $\mathrm{Zn}$ compared with the nonamended $\mathrm{C}$-control substrate.

At 3 WAP, geranium foliar chlorophyll levels were unaffected by treatment (Table 3 ). By 5 WAP, chlorophyll levels were similar in both control treatments, both of which were higher than chlorophyll levels in all slagamended geranium. Among geranium at 5 WAP, foliar chlorophyll levels increased with increasing slag rate. At $3 \mathrm{WAP}$, tomato foliar chlorophyll levels were highest in M-control substrates, followed by C-control substrates, both of which were higher than all slag-amended substrates. Foliar chlorophyll increased linearly with increasing slag rate. By 5 WAP, the treatment response with respect to differences between the two control groups and slag-amended substrates was similar to those at 3 WAP, although the magnitude of the differences was exacerbated. At 5 WAP, foliar chlorophyll levels in slag-amended substrates were very low independent of slag rate.

Although not compared statistically, there was very little change in geranium root ratings, within a treatment, from 3 to 5 WAP (Table 3). At both dates, root ratings were highest in the M-control substrate. At both

Table 1. Micronutrient content on a percent dry weight basis and amount of micronutrient applied from a commercial water-soluble fertilizer, a micronutrient fertilizer, and a steel slag amendment at one of three rates, when used as a micronutrient source in an 85:15 peatmoss:perlite substrate.

\begin{tabular}{|c|c|c|c|c|c|c|c|c|}
\hline \multirow[b]{3}{*}{ Nutrient } & \multirow{2}{*}{\multicolumn{2}{|c|}{ Water-soluble fertilizer ${ }^{2}$}} & \multirow{2}{*}{\multicolumn{2}{|c|}{ Granular micronutrients ${ }^{\mathrm{y}}$}} & \multicolumn{4}{|c|}{ Steel slag } \\
\hline & & & & & \multirow[b]{2}{*}{ Percent dry basis } & \multicolumn{3}{|c|}{ Applied } \\
\hline & Percent dry basis & $\overline{\text { Applied (mg) }}$ & Percent dry basis & Applied (mg) & & $1.2 \mathrm{~kg} \cdot \mathrm{m}^{-3}(\mathrm{mg})$ & $2.4 \mathrm{~kg} \cdot \mathrm{m}^{-3}(\mathrm{mg})$ & $4.8 \mathrm{~kg} \cdot \mathrm{m}^{-3}(\mathrm{mg})$ \\
\hline$\overline{\mathrm{B}}$ & 0.02 & 0.30 & 0.10 & 0.5 & 0.004 & 0.03 & 0.06 & 0.12 \\
\hline $\mathrm{Fe}$ & 0.10 & 1.50 & 17.00 & 90.8 & 20.300 & 146.16 & 292.32 & 584.64 \\
\hline $\mathrm{Mn}$ & 0.05 & 0.75 & 2.50 & 13.4 & 2.220 & 15.98 & 31.97 & 63.94 \\
\hline $\mathrm{Cu}$ & 0.01 & 0.15 & 1.00 & 5.3 & 0.004 & 0.03 & 0.06 & 0.12 \\
\hline Mo & 0.01 & 0.15 & 0.05 & 0.3 & 0.00017 & 0.00 & 0.00 & 0.00 \\
\hline $\mathrm{Zn}$ & 0.05 & 0.75 & 1.00 & 5.3 & 0.017 & 0.12 & 0.24 & 0.49 \\
\hline
\end{tabular}

zJack's $20 \mathrm{~N}-4.4 \mathrm{P}-16.6 \mathrm{~K}-0.15 \mathrm{Mg}-0.02 \mathrm{~B}-0.01 \mathrm{Cu}-0.1 \mathrm{Fe}-0.05 \mathrm{Mn}-0.01 \mathrm{Mo}-0.05 \mathrm{Zn}$, at a concentration of $100 \mathrm{mg} \cdot \mathrm{L}^{-1} \mathrm{nitrogen}(\mathrm{N})$.

${ }^{\mathrm{y}}$ Micromax, $6 \mathrm{Ca}-3 \mathrm{Mg}-12 \mathrm{~S}-0.1 \mathrm{~B}-17 \mathrm{Fe}-2.5 \mathrm{Mn}-1 \mathrm{Cu}-0.05 \mathrm{Mo}-1 \mathrm{Zn}$, at $0.9 \mathrm{~kg} \cdot \mathrm{m}^{-3}$.

xPlant Tuff, $0.004 \mathrm{~B}-20.3 \mathrm{Fe}-2.22 \mathrm{Mn}-0.004 \mathrm{Cu}-0.00017 \mathrm{Mo}-0.017 \mathrm{Zn}$, applied at rates of $1.2,2.4$, or $4.8 \mathrm{~kg} \cdot \mathrm{m}^{-3}$. 
dates, root ratings were lowest among slagamended substrates and there was no response among these treatments to slag rate. Among tomato, root ratings were likewise highest in $\mathrm{M}$-control treatments at $3 \mathrm{WAP}$, whereas all other treatments had similar root ratings. By $5 \mathrm{WAP}$, tomato root ratings in C-control and M-control substrates were similar, and both were higher than all slag-amended substrates. Tomato root ratings decreased linearly with increasing slag rate.

At 3 WAP, there were few and minor differences in geranium SDWs (Table 3). By 5 WAP, geranium in M-control substrates had greater shoot mass than all other treatments. Geranium in slag-amended substrates did not respond to slag rate, and all were smaller than both control treatments. Tomato SDWs at 3 WAP were similar among the two than all slag-amended treatments. By 5 WAP, tomato SDW was greatest in M-control substrates, followed by C-control substrates, both of which were greater than all slagamended substrates. Shoot dry weights in slagamended substrates increased with increasing control groups, both of which were greater

slag rate, but averaged overall slag rates, slag-amended tomatoes had less than half the mass of tomatoes in M-control substrates.

Substrate $\mathrm{pH}$ was highest in the Ccontrol substrates for both crops and harvest dates (Table 4). For each crop and harvest date, substrate $\mathrm{pH}$ increased with increasing slag rate so that $\mathrm{pH}$ in the highest slag rate $\left(4.8 \mathrm{~kg} \cdot \mathrm{m}^{-3}\right)$ was similar to $\mathrm{pH}$ in M-controls. The liming effect of steel slag in this experiment is similar to that previously reported for steel slag in peatmoss substrates (Altland et al., 2015). Both control treatments received $4.8 \mathrm{~kg} \cdot \mathrm{m}^{-3}$ dolomitic lime to adjust $\mathrm{pH}$. Although the M-controls were also amended with a granular micronutrient package, other research has shown that sulfate-based micronutrients have only a minor effect on substrate $\mathrm{pH}$ (Wright et al., 1999a, 1999b). Lower pH in Mcontrols is likely because of the higher potential acidity of the ammonium nitrate fertilizer compared with the commercial NPK formulation used in the C-control. Although not compared statistically, the overall trend in $\mathrm{pH}$ response in tomato pots was similar to geranium.

Table 2. Diethylene triamine pentaacetic acid (DTPA) extracted micronutrients from an 85 peatmoss : 15 perlite substrate that was either not amended (C-control), amended with $0.9 \mathrm{~kg} \cdot \mathrm{m}^{-3}$ of a micronutrient package $^{\mathrm{z}}$ (M-control), or amended with one of three rates of steel slag. ${ }^{y}$

\begin{tabular}{lcccccr}
\hline & $\begin{array}{c}\text { Rate } \\
\text { Amendment }\end{array}$ & $\mathrm{B}$ & $\mathrm{Fe}$ & $\mathrm{Mn}$ & $\mathrm{Cu}$ & $\mathrm{Zn}$ \\
\cline { 3 - 7 } & & & & $\left(\mathrm{mg} \cdot \mathrm{L}^{-1}\right)$ & & \\
\hline C-control & & 0.00 & 25.5 & 1.5 & 0.1 & 0.7 \\
M-control & & 0.20 & 42.7 & 8.3 & 4.1 & 6.9 \\
Slag & 1.2 & 0.03 & 38.8 & 1.9 & 0.1 & 0.6 \\
Slag & 2.4 & 0.02 & 32.6 & 4.6 & 0.0 & 0.5 \\
Slag & 4.8 & 0.02 & 31.0 & 10.2 & 0.1 & 0.6 \\
& & $\mathrm{~L}^{*}$ & $\mathrm{Q}^{*}$ & $\mathrm{~L}^{* * *}$ & $\mathrm{NS}$ & $\mathrm{NS}$ \\
LSD & & 0.01 & 8.3 & 3.6 & 0.3 & 0.5 \\
\hline
\end{tabular}

LSD $=$ least significant difference; $\mathrm{NS}=$ nonsignificant.

${ }^{2}$ Micromax, $6 \mathrm{Ca}-3 \mathrm{Mg}-12 \mathrm{~S}-0.1 \mathrm{~B}-17 \mathrm{Fe}-2.5 \mathrm{Mn}-1 \mathrm{Cu}-0.05 \mathrm{Mo}-1 \mathrm{Zn}$, at $0.9 \mathrm{~kg} \cdot \mathrm{m}^{-3}$.

y Plant Tuff, $0.004 \mathrm{~B}-20.3 \mathrm{Fe}-2.22 \mathrm{Mn}-0.004 \mathrm{Cu}-0.00017 \mathrm{Mo}-0.017 \mathrm{Zn}$, applied at rates of $1.2,2.4$, or $4.8 \mathrm{~kg} \cdot \mathrm{m}^{-3}$.

Table 3. Foliar chlorophyll, root ratings, and shoot dry weight of geranium (Pelargonium $\times$ hortorum 'Maverick Red') and tomato (Solanum lycopersicon 'Megabite') in an 85 peatmoss : 15 perlite substrate either fertilized with a complete water-soluble fertilizer ${ }^{2}$ (C-control), amended with a micronutrient package ${ }^{y}$ (M-control) or three rates of steel slag. ${ }^{x}$

\begin{tabular}{|c|c|c|c|c|c|c|c|c|}
\hline \multirow{2}{*}{$\begin{array}{l}\text { Harvest } \\
\text { date }\end{array}$} & \multirow[b]{2}{*}{ Amendment } & \multirow{2}{*}{$\begin{array}{c}\text { Rate } \\
\left(\mathrm{kg} \cdot \mathrm{m}^{-3}\right)\end{array}$} & \multicolumn{2}{|c|}{ Chlorophyll } & \multicolumn{2}{|c|}{ Root rating } & \multicolumn{2}{|c|}{ Shoot dry wt } \\
\hline & & & Geranium & Tomato & Geranium & Tomato & Geranium & Tomato \\
\hline \multirow{7}{*}{$3 \mathrm{WAP}^{\mathrm{w}}$} & C-control & & 25.5 & 27.8 & 2.0 & 2.8 & 2.0 & 5.0 \\
\hline & M-control & & 25.8 & 36.5 & 3.0 & 3.8 & 2.5 & 5.1 \\
\hline & Slag & 1.2 & 22.5 & 16.5 & 1.2 & 2.7 & 2.2 & 3.8 \\
\hline & Slag & 2.4 & 24.2 & 19.3 & 1.0 & 2.8 & 1.7 & 3.5 \\
\hline & Slag & 4.8 & 23.7 & 20.8 & 1.0 & 2.3 & 1.9 & 3.8 \\
\hline & Rate response $\mathrm{v}^{\mathrm{v}}$ & & NS & $\mathrm{L}^{* * *}$ & NS & NS & NS & NS \\
\hline & $\operatorname{LSD}_{0.05}{ }^{\mathrm{u}}$ & & NS & 2.0 & 0.2 & 0.5 & 0.5 & 0.3 \\
\hline \multirow[t]{7}{*}{$5 \mathrm{WAP}$} & C-control & & 20.2 & 19.6 & 1.8 & 3.8 & 5.5 & 12.4 \\
\hline & M-control & & 22.1 & 40.9 & 2.8 & 4.0 & 6.4 & 13.4 \\
\hline & Slag & 1.2 & 13.5 & 4.1 & 1.0 & 2.8 & 3.9 & 6.3 \\
\hline & Slag & 2.4 & 13.9 & 5.5 & 1.0 & 2.8 & 3.6 & 6.4 \\
\hline & Slag & 4.8 & 17.2 & 7.0 & 1.0 & 2.2 & 3.8 & 6.8 \\
\hline & Rate response & & $\mathrm{L}^{* *}$ & NS & NS & $\mathrm{L}^{* *}$ & NS & $\mathrm{L}^{*}$ \\
\hline & $\mathrm{LSD}_{0.05}$ & & 2.7 & 3.7 & 0.3 & 0.4 & 0.7 & 0.6 \\
\hline
\end{tabular}

zJack's $20 \mathrm{~N}-4.4 \mathrm{P}-16.6 \mathrm{~K}-0.15 \mathrm{Mg}-0.02 \mathrm{~B}-0.01 \mathrm{Cu}-0.1 \mathrm{Fe}-0.05 \mathrm{Mn}-0.01 \mathrm{Mo}-0.05 \mathrm{Zn}$, at a concentration of $100 \mathrm{mg} \cdot \mathrm{L}^{-1}$ nitrogen $(\mathrm{N})$

${ }^{y}$ Micromax, $6 \mathrm{Ca}-3 \mathrm{Mg}-12 \mathrm{~S}-0.1 \mathrm{~B}-17 \mathrm{Fe}-2.5 \mathrm{Mn}-1 \mathrm{Cu}-0.05 \mathrm{Mo}-1 \mathrm{Zn}$, at $0.9 \mathrm{~kg} \cdot \mathrm{m}^{-3}$.

${ }^{x}$ Plant Tuff, $0.004 \mathrm{~B}-20.3 \mathrm{Fe}-2.22 \mathrm{Mn}-0.004 \mathrm{Cu}-0.00017 \mathrm{Mo}-0.017 \mathrm{Zn}$, applied at rates of $1.2,2.4$, or $4.8 \mathrm{~kg} \cdot \mathrm{m}^{-3}$.

${ }^{w}$ Weeks after planting.

${ }^{\vee} \mathrm{L}$ or NS represents linear or nonsignificant response to slag rate at the $0.05,0.01$, or 0.001 (*, **, or ***, respectively) level of significance.

"Least significant difference (LSD) according to Fisher's test where $\alpha=0.05$.
With each crop and date of harvest, EC increased linearly with increasing slag rate (Table 4). Nonetheless, differences in substrate EC were unremarkable and EC among all treatments, crops, and dates of collection were within the recommended range of 1.0 to $3.5 \mathrm{mS} \cdot \mathrm{cm}^{-1}$ for floriculture crops in soilless substrates (Cavins et al., 2000).

Geranium foliar B concentration was highest in M-control plants at $3 \mathrm{WAP}$ and similar among all other treatments (Table 5). By 5 WAP, geranium foliar B concentration was still highest in M-controls, whereas concentration increased with increasing slag rate. By the end of the study, only M-controls had higher than recommended foliar B for geranium. Tomato foliar B levels at $3 \mathrm{WAP}$ were likewise highest in the M-control treatment, followed by the C-control treatment, with tomatoes in slag-amended substrates with the lowest concentrations. Tomato foliar $\mathrm{B}$ increased with increasing slag rate at 3 and 5 WAP. At 5 WAP, M-control and C-control treatments had similar foliar B concentrations, both of which were greater than all tomato in slag-amended substrates. DTPAextractable B levels were higher in M-control substrates (Table 2). Albeit very low, DTPAextractable $\mathrm{B}$ increased with increasing slag rate. All leachate $B$ levels were extremely low, and beneath the level of detection for most samples (Table 4). Only the M-control leachates at 3 WAP for geranium and tomato had consistently detectable B concentrations across all replications (data not shown). Low $\mathrm{B}$ levels in leachates and DTPA extractions are typical for soilless substrates (Berghage et al., 1987), and thus low values for these two analyses are not strong indicators or predictors of B deficiency in plants.

Geranium foliar $\mathrm{Fe}$ concentrations were similar across treatments throughout the experiment (Table 5). Averaging across all treatments, geranium $\mathrm{Fe}$ concentrations were 70 and $59 \mathrm{mg} \cdot \mathrm{kg}^{-1}$ at 3 and $5 \mathrm{WAP}$, respectively. Tomato foliar Fe concentrations were affected by treatment, with those in the $\mathrm{M}$-control having higher foliar Fe than most other treatments. Similar to geranium, foliar $\mathrm{Fe}$ was similar in response to slag rate in tomato. Despite being below recommended levels, neither geranium nor tomato in the control groups displayed any symptoms of $\mathrm{Fe}$ deficiency. DTPA-extractable Fe was highest in the M-control substrate, despite higher amounts of $\mathrm{Fe}$ applied via the slag treatments. DTPA-extractable $\mathrm{Fe}$ increased from the nonamended substrate (C-control) to the low slag rate and then decreased with increasing slag rate. Although increasing the slag rate results in greater $\mathrm{Fe}$ additions to the substrate (Table 1), the higher $\mathrm{pH}$ as a result of the increased slag rate reduced the amount of $\mathrm{Fe}$ available for plant uptake. Leachate $\mathrm{Fe}$ concentrations were higher in the $\mathrm{C}$-controls than all other treatments in both crops and both harvest dates (Table 4). This was surprising considering that the C-control treatment resulted in far less applied Fe compared with all other treatments (Table 1). The reason for higher Fe leachate levels in the 
Table 4. Leachate electrical conductivity (EC), $\mathrm{pH}$, and nutrient concentration from geranium (Pelargonium $\times$ hortorum 'Maverick Red') and tomato (Solanum lycopersicon 'Megabite') in an 85:15 peatmoss:perlite substrate amended with a complete water-soluble fertilizer ${ }^{2}$ (C-control), amended with a micronutrient package ${ }^{y}$ (M-control) or three rates of steel slag. ${ }^{x}$

\begin{tabular}{|c|c|c|c|c|c|c|c|c|c|}
\hline Crop & Harvest & Amendment & Rate $\left(\mathrm{kg} \cdot \mathrm{m}^{-3}\right)$ & $\mathrm{pH}$ & $\mathrm{EC}$ & $\mathrm{B}$ & $\mathrm{Fe}$ & $\mathrm{Mn}$ & $\mathrm{Zn}$ \\
\hline \multirow[t]{14}{*}{ Geranium } & $3 \mathrm{WAP}^{\mathrm{w}}$ & C-control & & 6.27 & 0.9 & 0.02 & 1.63 & 0.08 & 0.47 \\
\hline & & M-control & & 5.47 & 1.5 & 0.18 & 0.31 & 1.80 & 0.25 \\
\hline & & Slag & 1.2 & 4.95 & 1.0 & 0.00 & 0.31 & 0.37 & 0.06 \\
\hline & & Slag & 2.4 & 5.28 & 1.5 & 0.00 & 0.20 & 0.34 & 0.0 \\
\hline & & Slag & 4.8 & 5.66 & 1.7 & 0.01 & 0.17 & 0.58 & 0.06 \\
\hline & & Rate response $\mathrm{e}^{\mathrm{v}}$ & & $\mathrm{L}^{* * *}$ & $\mathrm{~L}^{* * *}$ & NS & NS & $\mathrm{L}^{*}$ & NS \\
\hline & & $\operatorname{LSD}_{0.05^{\mathrm{u}}}$ & & 0.14 & 0.2 & 0.0 & 0.15 & 0.16 & 0.10 \\
\hline & 5 WAP & C-control & & 6.11 & 1.1 & 0.01 & 1.00 & 0.05 & 0.1 \\
\hline & & M-control & & 5.40 & 1.2 & 0.01 & 0.21 & 0.99 & 0.1 \\
\hline & & Slag & 1.2 & 4.65 & 1.7 & 0.00 & 0.23 & 0.74 & 0.0 \\
\hline & & Slag & 2.4 & 5.20 & 1.8 & 0.00 & 0.23 & 0.24 & 0.0 \\
\hline & & Slag & 4.8 & 5.37 & 2.3 & 0.00 & 0.11 & 0.40 & 0.00 \\
\hline & & Rate response & & $\mathrm{L}^{* * *}$ & $\mathrm{~L}^{* * *}$ & NS & NS & $\mathrm{L}^{*}$ & NS \\
\hline & & $\mathrm{LSD}_{0.05}$ & & 0.19 & 0.3 & 0.01 & 0.18 & 0.26 & 0.0 \\
\hline \multirow{14}{*}{ Tomato } & 3 WAP & C-control & & 6.38 & 0.2 & 0.00 & 1.43 & 0.04 & 0.2 \\
\hline & & M-control & & 5.56 & 0.4 & 0.06 & 0.44 & 0.70 & 0.1 \\
\hline & & Slag & 1.2 & 5.03 & 0.4 & 0.00 & 0.31 & 0.18 & 0.0 \\
\hline & & Slag & 2.4 & 5.58 & 0.5 & 0.00 & 0.22 & 0.14 & 0.0 \\
\hline & & Slag & 4.8 & 5.83 & 0.7 & 0.00 & 0.16 & 0.29 & 0.00 \\
\hline & & Rate response & & $\mathrm{L}^{* * *}$ & $\mathrm{~L}^{* * *}$ & NS & NS & $\mathrm{L}^{*}$ & NS \\
\hline & & $\mathrm{LSD}_{0.05}$ & & 0.18 & 0.1 & 0.03 & 0.15 & 0.13 & 0.0 \\
\hline & $5 \mathrm{WAP}$ & C-control & & 6.30 & 0.1 & 0.00 & 1.26 & 0.02 & 0.3 \\
\hline & & M-control & & 5.95 & 0.2 & 0.00 & 0.27 & 0.24 & 0.0 \\
\hline & & Slag & 1.2 & 5.01 & 0.8 & 0.00 & 0.25 & 0.24 & 0.0 \\
\hline & & Slag & 2.4 & 5.42 & 0.9 & 0.00 & 0.18 & 0.23 & 0.0 \\
\hline & & Slag & 4.8 & 5.59 & 1.1 & 0.00 & 0.11 & 0.28 & 0.0 \\
\hline & & Rate response & & $\mathrm{L}^{* *}$ & $L^{* * *}$ & NS & $\mathrm{L}^{* *}$ & NS & NS \\
\hline & & $\operatorname{LSD}_{0.05}$ & & 0.42 & 0.2 & NS & 0.10 & 0.08 & 0.0 \\
\hline
\end{tabular}

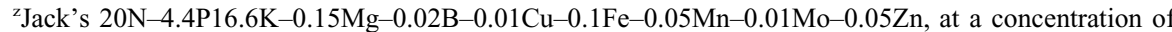
$100 \mathrm{mg} \cdot \mathrm{L}^{-1}$ nitrogen $(\mathrm{N})$.

${ }^{y}$ Micromax, $6 \mathrm{Ca}-3 \mathrm{Mg}-12 \mathrm{~S}-0.1 \mathrm{~B}-17 \mathrm{Fe}-2.5 \mathrm{Mn}-1 \mathrm{Cu}-0.05 \mathrm{Mo}-1 \mathrm{Zn}$, at $0.9 \mathrm{~kg} \cdot \mathrm{m}^{-3}$

${ }^{x}$ Plant Tuff, $0.004 \mathrm{~B}-20.3 \mathrm{Fe}-2.22 \mathrm{Mn}-0.004 \mathrm{Cu}-0.00017 \mathrm{Mo}-0.017 \mathrm{Zn}$, applied at rates of $1.2,2.4$, or $4.8 \mathrm{~kg} \cdot \mathrm{m}^{-3}$.

${ }^{\mathrm{w}}$ Weeks after planting.

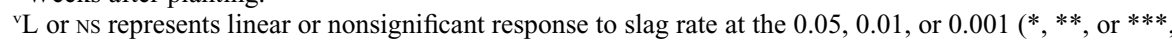
respectively) level of significance.

"Least significant difference (LSD) according to Fisher's test where $\alpha=0.05$.

C-control is likely because the fertilizer used in the C-control contains a chelated $\mathrm{Fe}$ formulation, whereas $\mathrm{Fe}$ in the M-control was from $\mathrm{FeSO}_{4} \cdot \mathrm{H}_{2} \mathrm{O}$. Others have shown greater solubility of $\mathrm{Fe}$ in chelated form compared with other mineral forms (Broschat and Donselman, 1985; Smilde, 1975). Leached $\mathrm{Fe}$ from the slag-amended substrates tended to decrease with increasing rate; however, this trend was only significant among tomato at $6 \mathrm{WAP}$. Low leachate Fe concentrations from steel slag treatments are somewhat surprising, considering that the slag used in this experiment is composed of $25.9 \% \mathrm{FeO}$ and the quantity of $\mathrm{Fe}$ applied in these treatments are several orders of magnitude greater than that applied in the C-controls (Table 1). Ferrous oxide in the steel slag consists of the divalent form of $\mathrm{Fe}$, which is water soluble and readily available to plants (Mills and Jones, 1996). However, exposure of ferrous oxide to well-aerated soilless substrates can cause oxidation to the trivalent form, which is insoluble in water thus not available for plant uptake. Lack of Fe uptake is also evident in geranium tissue concentrations. Lee et al. (1996) showed that seed geranium tissue $\mathrm{Fe}$ concentrations would increase with increasing solution Fe concentration in the substrate. Lack of response to increasing Fe along with increasing slag rate suggests that $\mathrm{Fe}$ from the
DTPA-extractable $\mathrm{Cu}$ was similar among the nonamended substrate (C-control) and all slag-amended substrates (Table 2). Lack of $\mathrm{Cu}$ in slag-amended substrates might be the primary reason for poor growth and exacerbated deficiency symptoms in those plants. Although the C-control substrate also had very low DTPA-extractable $\mathrm{Cu}$ concentrations, this treatment received regular application of chelated $\mathrm{Cu}$ via the water-soluble fertilizer throughout the experiment. The slag-amended plants would not receive any additional $\mathrm{Cu}$ beyond what was supplied via the preincorporated slag amendment. Teicher and Fischer (1986) found that across 30 samples of sphagnum peat collected from bogs throughout Europe, all had extremely low concentrations of $\mathrm{Cu}$. Likewise, Penningsfeld (1972) showed that by systematically excluding individual micronutrients in a peat-based substrate, excluding $\mathrm{Cu}$ was the only nutrient to reduce growth and flowering of primroses (Primula obconica Hance 'Bayernblut'). Leachate $\mathrm{Cu}$ levels were generally below the detection level and thus not reported.

In both crops and dates, foliar Mo was highest in C-control plants, whereas all other treatments were similar to each other and lower than C-control. The quantity of Mo applied via the $\mathrm{C}$-control and $\mathrm{M}$-control treatments was roughly similar, while the concentration of Mo in the steel slag was so low that the applied amount was negligible (Table 1). Considering the amount of Mo in the two control groups was similar, it is surprising that Mo levels in foliar tissue are so much higher for the $\mathrm{C}$-control plants. Molybdenum in the $\mathrm{C}$-control fertilizer was in the form of ammonium molybdate, whereas that in the M-control was sodium molybdate. Both compounds are very soluble in water $(0.43$ and $0.84 \mathrm{~kg} \cdot \mathrm{L}^{-1}$ for ammonium and sodium molybdate, respectively). Greater quantity of Mo might have been available for plant uptake in higher $\mathrm{pH}$ substrates of the C-controls. Smilde (1975) showed that foliar tissue concentrations $\mathrm{B}, \mathrm{Fe}, \mathrm{Mn}$, and $\mathrm{Zn}$ in chrysanthemum (Dendranthema $\times$ grandiflorum L. 'Neptune') decreased with increasing lime application, while only Mo among all micronutrients increased. Likewise, Cox (1988) showed lime applications that raised $\mathrm{pH}$ of a peatmoss substrate alleviated Mo deficiency symptoms in poinsettia (Euphorbia pulcherrima Willd. ex Klotz). Foliar Mo concentration of plants amended with steel slag was similar to M-controls despite no appreciable additions via the steel slag amendment. Molybdenum is required by plants in lower quantities than any other nutrient with the exception of $\mathrm{Ni}$ (Marschner, 1997). Trace amounts of Mo in the peatmoss substrate were not likely sufficient to meet plant needs.

Among geranium at both dates, foliar $\mathrm{Zn}$ was highest in M-control plants whereas all slag-amended plants were below recommended levels (Table 5). Likewise, tomato amended with the M-control also had the highest foliar $\mathrm{Zn}$ concentration. However, all tomato leaf tissue samples in all treatments at both dates were above recommended levels. 
Table 5. Foliar nutrient concentration in geranium (Pelargonium ×hortorum 'Maverick Red') and tomato (Solanum lycopersicon 'Megabite') in an 85:15 peatmoss:perlite substrate amended with a complete water-soluble fertilizer ${ }^{\mathrm{z}}$ (C-control), amended with a micronutrient package ${ }^{\mathrm{y}}(\mathrm{M}-\mathrm{control})$ or three rates of steel slag. ${ }^{\mathrm{x}}$

\begin{tabular}{|c|c|c|c|c|c|c|c|c|c|c|}
\hline Crop & Harvest & Amendment & Rate $\left(\mathrm{kg} \cdot \mathrm{m}^{-3}\right)$ & B & $\mathrm{Fe}$ & $\mathrm{Mn}$ & $\mathrm{Cu}$ & Mo & $\mathrm{Zn}$ & $\mathrm{Si}$ \\
\hline \multirow[t]{14}{*}{ Geranium } & \multirow[t]{5}{*}{$3 \mathrm{WAP}^{\mathrm{w}}$} & C-control & & 50.0 & 71.4 & 83.3 & 1.7 & 4.7 & 57.2 & 119.7 \\
\hline & & M-control & & 65.2 & 66.8 & 449.6 & 11.0 & 0.4 & 69.6 & 114.7 \\
\hline & & Slag & 1.2 & 46.1 & 67.6 & 189.9 & 0.8 & 0.1 & 30.0 & 677.2 \\
\hline & & Slag & 2.4 & 50.6 & 72.0 & 201.5 & 0.7 & 0.2 & 33.9 & 610.5 \\
\hline & & Slag & 4.8 & 52.8 & 72.3 & 219.5 & 0.7 & 0.2 & 28.5 & 826.1 \\
\hline & \multicolumn{3}{|l|}{ Rate response $\mathrm{v}^{\mathrm{v}}$} & NS & NS & $\mathrm{L}^{*}$ & NS & NS & NS & NS \\
\hline & \multicolumn{3}{|l|}{$\mathrm{LSD}_{0.05^{\mathrm{u}}}$} & 8.8 & NS & 24.7 & 1.0 & 0.8 & 13.6 & 248.8 \\
\hline & \multirow[t]{5}{*}{5 WAP } & C-control & & 25.9 & 64.4 & 63.5 & 0.5 & 9.5 & 37.0 & 272.4 \\
\hline & & M-control & & 36.7 & 62.4 & 383.3 & 8.1 & 0.2 & 57.8 & 173.7 \\
\hline & & Slag & 1.2 & 20.2 & 55.4 & 195.6 & 0.1 & 0.1 & 28.1 & 738.7 \\
\hline & & Slag & 2.4 & 23.0 & 57.7 & 189.9 & 0.2 & 0.2 & 23.5 & 821.1 \\
\hline & & Slag & 4.8 & 27.4 & 56.2 & 233.9 & 0.6 & 0.3 & 23.5 & 912.7 \\
\hline & \multicolumn{3}{|l|}{ Rate response } & $\mathrm{L} * * *$ & NS & $\mathrm{L}^{* * *}$ & NS & NS & NS & $\mathrm{L}^{*}$ \\
\hline & \multicolumn{3}{|l|}{$\mathrm{LSD}_{0.05}$} & 3.5 & NS & 21.4 & 0.7 & 0.7 & 10.0 & 171.4 \\
\hline \multicolumn{4}{|c|}{ Recommended minimum ${ }^{\mathrm{t}}$} & 35 & 70 & 110 & 5 & - & 36 & - \\
\hline \multirow[t]{14}{*}{ Tomato } & \multirow[t]{5}{*}{$3 \mathrm{WAP}$} & C-control & & 37.3 & 66.9 & 33.4 & 2.2 & 6.5 & 48.4 & 344.3 \\
\hline & & M-control & & 53.1 & 74.6 & 298.2 & 14.2 & 0.6 & 96.4 & 258.1 \\
\hline & & Slag & 1.2 & 29.4 & 59.1 & 118.9 & 3.7 & 0.3 & 28.5 & 686.0 \\
\hline & & Slag & 2.4 & 30.6 & 56.5 & 127.4 & 3.5 & 0.4 & 22.6 & 1010.3 \\
\hline & & Slag & 4.8 & 33.7 & 58.9 & 150.4 & 0.8 & 0.5 & 19.9 & 1016.0 \\
\hline & \multicolumn{3}{|l|}{ Rate response } & $\mathrm{L} * * *$ & NS & $\mathrm{L}^{* * *}$ & NS & NS & $\mathrm{L}^{* *}$ & $\mathrm{~L}^{* * *}$ \\
\hline & \multicolumn{3}{|l|}{$\mathrm{LSD}_{0.05}$} & 2.3 & 7.3 & 15.5 & 6.0 & 0.5 & 5.5 & 97.2 \\
\hline & \multirow[t]{5}{*}{5 WAP } & C-control & & 22.7 & 44.9 & 28.3 & 4.3 & 5.4 & 35.2 & 237.1 \\
\hline & & M-control & & 25.1 & 57.7 & 221.8 & 8.5 & 0.3 & 81.1 & 223.3 \\
\hline & & Slag & 1.2 & 13.1 & 47.2 & 143.7 & 9.6 & 0.3 & 27.1 & 665.4 \\
\hline & & Slag & 2.4 & 15.3 & 51.1 & 117.3 & 1.3 & 1.4 & 35.6 & 989.3 \\
\hline & & Slag & 4.8 & 17.3 & 45.3 & 134.2 & 0.9 & 0.5 & 20.7 & 974.7 \\
\hline & \multicolumn{3}{|l|}{ Rate response } & $\mathrm{L}^{* *}$ & NS & NS & NS & NS & NS & $\mathrm{L}^{* *}$ \\
\hline & \multicolumn{3}{|l|}{$\mathrm{LSD}_{0.05}$} & 2.9 & 7.9 & 31.7 & NS & 1.2 & 14.5 & 150.9 \\
\hline \multicolumn{4}{|c|}{ Recommended minimum ${ }^{\mathrm{s}}$} & 45 & 84 & 55 & 6 & - & 20 & - \\
\hline
\end{tabular}

Jack's $20 \mathrm{~N}-4.4 \mathrm{P}-16.6 \mathrm{~K}-0.15 \mathrm{Mg}-0.02 \mathrm{~B}-0.01 \mathrm{Cu}-0.1 \mathrm{Fe}-0.05 \mathrm{Mn}-0.01 \mathrm{Mo}-0.05 \mathrm{Zn}$, at a concentration of $100 \mathrm{mg} \cdot \mathrm{L}^{-1} \mathrm{nitrogen}(\mathrm{N})$.

${ }^{\mathrm{y}}$ Micromax, $6 \mathrm{Ca}-3 \mathrm{Mg}-12 \mathrm{~S}-0.1 \mathrm{~B}-17 \mathrm{Fe}-2.5 \mathrm{Mn}-1 \mathrm{Cu}-0.05 \mathrm{Mo}-1 \mathrm{Zn}$, at $0.9 \mathrm{~kg} \cdot \mathrm{m}^{-3}$.

xPlant Tuff, 0.004B-20.3Fe-2.22Mn-0.004Cu-0.00017Mo-0.017Zn, applied at rates of $1.2,2.4$, or $4.8 \mathrm{~kg} \cdot \mathrm{m}^{-3}$.

wheeks after planting.

${ }^{\vee} \mathrm{L}$ or NS represents linear or nonsignificant response to slag rate at the $0.05,0.01$, or $0.001(*, * *$, or $* * *$, respectively) level of significance.

"Least significant difference (LSD) according to Fisher's test where $\alpha=0.05$.

tKrug et al. (2010).

${ }^{\mathrm{s}}$ Mills and Jones (1996).

Leachate $\mathrm{Zn}$ concentrations were higher in the C-controls compared with the M-controls, with the exception of geranium at $6 \mathrm{WAP}$ (Table 4). Leachate $\mathrm{Zn}$ concentrations were lower in all slag-amended substrates compared with the $\mathrm{C}$-controls, and did not respond to slag rate. The slag material was comprised of $0.02 \%$ $\mathrm{Zn}$ while the fertilizer used in the M-control was $1.0 \% \mathrm{Zn}$. Even at the highest slag rate used, there would be 10 times more $\mathrm{Zn}$ in the M-control fertilizer than what is provided from the slag amendment.

In summary, chlorophyll ratings, root ratings, and shoot mass of both species were similar to, or in most cases, greater in M-control substrates compared with C-control. This could be the result of a more favorable response to lower $\mathrm{pH}$ in $\mathrm{M}$-control substrates compared with $\mathrm{C}$-control substrates. The more favorable response to M-control substrates could also be the result of incorporating the granular micronutrients in those treatments compared with the gradual application of water-soluble micronutrients in the C-controls. And finally, the mass of micronutrients applied was in all cases greater for the M-control treatment compared with the $\mathrm{C}$-control treatment (Table 1), most notable Fe, $\mathrm{Mn}, \mathrm{Cu}$, and $\mathrm{Zn}$. Although both of these fertilization methods are common, they are not equal in terms of the mass of each micronutrient applied. Despite differences in the two control groups, their purpose was only to serve as two common but different comparisons for steel slag as a source of micronutrients. Both control groups resulted in vigorous and saleable plants by the conclusion of the experiment.

The primary objective of this research was to determine if steel slag could be used as the sole micronutrient source for container-grown floriculture crops. The steel slag rates applied in this experiment would be typical of rates used for adjusting substrate $\mathrm{pH}$ (Altland et al., 2015). At these rates, $\mathrm{B}, \mathrm{Cu}$, and $\mathrm{Zn}$ are lower than what would be applied with water-soluble or granular incorporated micronutrients (Table 1). The quantity of DTPA-extractable $\mathrm{Cu}$ or $\mathrm{Zn}$ is not significantly higher than substrates with no micronutrient amendment (Table 2). While DTPA-extractable $\mathrm{Fe}$ in substrates amended with the low steel slag rate were higher than nonamended controls and similar to the M-controls, Fe decreased with increasing steel slag rate, presumably as a function of increasing $\mathrm{pH}$. Geranium and tomato response to steel slag amendments reflect these initial measurements displaying the lack of micronutrient availability, in that growth and development was reduced compared with control plants. In both crops, chlorophyll levels, root ratings, and shoot dry mass were lower in all steel slag-amended plants compared with either control group by 5 WAP. Determining which combination of nutrients is responsible for the reduced growth of geranium and tomato is difficult as reduced growth from one nutrient deficiency might aggravate another deficiency. In geranium, foliar nutrient concentrations suggest $\mathrm{Cu}$ and $\mathrm{Zn}$ were limiting due to the concentrations found in steel slag-amended crops relative to the control groups and the recommended minimums. In tomato plants, foliar nutrient concentrations suggest $\mathrm{B}$ and $\mathrm{Zn}$ were limiting. Based on the results of this research, steel slag does not provide sufficient micronutrients, most notably $\mathrm{B}, \mathrm{Cu}$, and $\mathrm{Zn}$, to be the sole source of micronutrient fertilization in container-grown crops. In previous research with the same steel slag rates (Altland et al., 2015), sunflower (Helianthus annuus L. 'Pacino Gold') grew well regardless of steel slag rate when a complete watersoluble fertilizer with micronutrients was used. The steel slag used in this experiment provides some micronutrients for container substrates, but cannot be used as the sole source for micronutrients.

\section{Literature Cited}

Adams, P., M.H. Adatia, C.J. Graves, and G.W. Winsor. 1986. Some effects of micronutrients 
and liming on the yield, quality, and micronutrient status of cucumbers grown in peat. Acta Hort. 178:199-204.

Ali, M.T. and S.H. Shahram. 2007. Converter slag as a neutralizing agent in the amelioration of acidic soils. Intl. J. Agr. Biol. 9:715-720.

Altland, J.E., J.C. Locke, W.L. Zellner, and J.K. Boldt. 2015. Steel slag raises $\mathrm{pH}$ of greenhouse substrates. HortScience 50:603-608.

Berghage, R.D., D.M. Krauskopf, D.D. Warncke, and I. Widders. 1987. Micronutrient testing of plant growth media: Extractant identification and evaluation. Commun. Soil Sci. Plant Anal. 18:1089-1109.

Broschat, T.K. and H.M. Donselman. 1985. Extractable $\mathrm{Mg}, \mathrm{Fe}, \mathrm{Mn}, \mathrm{Zn}$, and $\mathrm{Cu}$ from a peatbased container medium amended with various micronutrient fertilizers. J. Amer. Soc. Hort. Sci. 110:196-200.

Cavins, T.J., B.E. Whipker, W.C. Fonteno, B. Harden, I. McCall, and J.L. Gibson. 2000. Monitoring and managing $\mathrm{pH}$ and $\mathrm{EC}$ using the pourthru extraction method. NC State University Horticulture Information Leaflet 590.

Cox, D.A. 1988. Lime, molybdenum, and cultivar effects on molybdenum deficiency of poinsettia. J. Plant Nutr. 11:589-603.
Frost, M.D., J.C. Cole, and J.M. Dole. 2003. Fertilizer source affects iron, manganese, and zinc leaching, nutrient distribution, and geranium growth. J. Plant Nutr. 26:315-329.

Krug, B.A., B.E. Whipker, and I. McCall. 2010. Geranium leaf tissue nutrient sufficiency ranges by chronological age. J Plant Nutr. 33:339-350.

Lee, C.W., J. Choi, and C. Pak. 1996. Micronutrient toxicity in seed geranium (Pelargonium xhortorum Bailey). J. Amer. Soc. Hort. Sci. 121:77-82.

Marschner, H. 1997. Mineral nutrition of higher plants. 2nd ed. Academic Press, San Diego, CA.

Mills, H.A. and J.B. Jones. 1996. Plant analysis handbook II. Micro-Macro Publishing. Athens, GA.

Penningsfeld, F. 1972. Macro and micro nutrients of pot plants in peat. Acta Hort. 26:81-102.

Peterson, J.C. 1980. Effects of $\mathrm{pH}$ upon nutrient availability in a commercial soilless root medium utilized for floral crop production. Ohio Agr. Res. Dev. Ctr. Circ. 268:16-19.

Rodriguez, M., F.A. Lopez, M. Pinto, N. Balcazar, and G. Besga. 1994. Basic Linz-Donawitz slag as a neutralizing agent for pastureland. Agron. J. 86:904-909.

Smilde, K.W. 1975. Micronutrient requirements of chrysanthemums grown on peat substrates. Acta Hort. 50:101-113.
Smith, B.R., P.R. Fisher, and W.R. Argo. 2004. Water-soluble fertilizer concentration and $\mathrm{pH}$ of a peat-based substrate affect growth, nutrient uptake, and chlorosis of container-grown seed geraniums. J. Plant Nutr. 27:497-524.

Teicher, K. and P. Fischer. 1986. Macro- and micronutrients in sphagnum peats. Acta Hort 178:189-198.

Warncke, D.D. 1990. Testing artificial growth media and interpreting the results, p. 337357. In: Soil testing and plant analysis. 3rd ed. Soil Sci. Soc. Amer., Madison, WI.

Wright, A.N., A.X. Niemiera, J.R. Harris, and R.D. Wright. 1999a. Micronutrient fertilization of woody seedlings essential regardless of pine bark pH. J. Environ. Hort. 17:69-72.

Wright, A.N., A.X. Niemiera, J.R. Harris, and R.D. Wright. 1999b. Preplant lime and micronutrient amendments to pine bark affect growth of seedlings of nine container-grown tree species. HortScience 34:669-673.

Yeager, T.H., C.H. Gilliam, T.E. Bilderback, D.C. Fare, A.X. Niemiera, and K.M. Tilt. 2007. Best management practices: Guide for producing nursery crops. Southern Nursery Assoc., Atlanta, GA.

Yildirim, I.Z. and M. Prezzi. 2011. Chemical, mineralogical, and morphological properties of steel slag. Adv. Civ. Eng. 2011(1):1-13. 